\title{
Analyzing Socio-Economic and Geographical Factors that Affect the Health of the Elderly
}

\author{
Zacharias Dermatis $^{1} \cdot$ Athina Lazakidou $^{2} \cdot$ Athanasios Anastasiou $^{1}$ (D) \\ Panagiotis Liargovas ${ }^{2}$
}

Received: 17 May 2019 / Accepted: 13 September 2020 / Published online: 17 October 2020

C Springer Science+Business Media, LLC, part of Springer Nature 2020

\begin{abstract}
The aim of the current research is mainly to investigate socio-economic indicators that affect the health status of the elderly. Specific objectives are the recording of the current profile of the elderly and the investigation of the perception of the health status by elderly, the proportion of older people suffering from health problems, their most common health problems, the percentage of elderly whose health status affects their life quality, the overall life quality of elderly, and the degree of correlation of socioeconomic indicators to the quality of life of elderly. A sample of 897 questionnaires, collected from a number of open elderly care centers in Greece, was the basis of the current survey. The collected data concerning the location of certain health problems and aspects of perceived general health and perceived quality of life of participants were located automatically in geographic maps as geographic information systems (GIS), in order to be shared and analyzed easily. There is almost complete coincidence of our research findings and their statistical analysis with the theoretical approaches of the related literature, with the exception of the relation of marital status with the perception of the quality of life. Direct geographic mapping aims at identifying health problems and socio-economic indicators of the elderly in Greece and transferring information to healthcare professionals in order to impose proper control measures in a very small period of time.
\end{abstract}

Keywords E-health · Social geography · Socio-economic factors · Elderly people · Quality of life - GIS

Zacharias Dermatis

zderm@uop.gr

1 Department of Management Science and Technology, School of Economics and Technology, University of Peloponnese, Tripolis, Greece

2 Department of Economics, Digital Health Applications and Health Economics Analytics Laboratory, School of Economy, Management and Informatics, University of Peloponnese, Tripolis, Greece 


\section{Introduction}

Nowadays, studies of the elderly have attained important significance due to the aging of the population across the globe. The elderly are confronted with a number of problems that have to do with both physical threats to health and psychological and biological problems. Elderly people are subject to feelings of insecurity, exclusion, and abandonment. In addition, the decline in their physical abilities gradually leads to the inability to treat illnesses or to psychological disorganization. Moreover, economic difficulties due to inadequate retirement and inefficient healthcare can lead to further isolation and worsening of the state of psychosomatic problems of the elderly.

Thus, people at the third age exhibit new needs that can be analyzed from various perspectives offering new insights on the way that the elderly perceive and behave in modern societies. Unequivocally, socio-economic and geographical factors of the elderly population underlie the core of the relevant studies providing the base to schedule services and interventions to them. This kind of data should be easily accessible and open to the public - a central issue of modern e-government. The use of geographical information systems (GIS) highly facilitates this direction as they permit easy open access to the data. In the present article, such an interpretation for the elderly population in Greece is presented.

Similar surveys have been carried out in Europe and elsewhere. In Europe, a long-term research is carried out having the title Survey on Health, Aging and Retirement in Europe (SHARE), the first results of which were published during 2005 (Börsch-Supan and Jürges 2005). SHARE started with eleven countries across Europe, but gradually the number of countries included in the survey exceeded sixteen countries. Collection of data is continuously increased, and new conclusions are extracted (Börsch-Supan et al. 2008). Similar surveys are Health and Retirement Study (HRS) in the USA and Longitudinal Study of Aging (ELSA) in the UK. Moreover, surveys similar to the HRS are carried out in Russian Federation and other Asiatic and African countries (Kapteyn 2008).

According to Carone and Costello (2006), the significance of such surveys lies in the fact that they could affect the economic policy of the European Union, since the provided data could be used for important reforms concerning sustainable pension systems. Such surveys could also be used to understand the uncertainty of economic and demographic changes and could provide a valuable tool to assess the quality of life and health of elderly and how they affected by several social and economic factors.

Some examples of the related existing international surveys are listed in the following table (Table 1):

However, the scope of the current research is the investigation of the existing differentiation in the socio-economic characteristics and the lifestyle of adults in Greece, in different geographical areas (urban, semi-urban, rural), the degree of treatment of these differentiated characteristics by geographical area, and the exploration of the possibility of more easily addressing these differences using GIS as a tool for their visualization. Thus, this research fills a research gap regarding the use of GIS to reflect geographical differences in socio-economic characteristics and lifestyle of elderly in Greece, as well as the possibility of use of this system for direct and geographically targeted interventions for solving the problems that arise due to these differences.

Elderly people receive various social services helping their psychosomatic conditions and providing entertainment to them. The most important structures placed in the 
Table 1 Examples of the related existing international surveys

Asthma

Wellie et al. 2000

Bernstein et al. 2005

Oyana et al. 2004

Oyana and Rivers 2005

Manfreda et al. 2004

Habbick et al. 1999

Chronic obstructive pulmonary disease

Buckeridge et al. 2002

Myocardial infarction

O’Neill 2003

Viik-Kajander et al. 2003

Bronchitis

Foggin and Aurillon 1989

Levesque et al. 1998

Pneumonia

Mikelova et al. 2003

Diekema et al. 2001

Veugelers et al. 1994

Flu

Uphoff et al. 2004

Harcourt et al. 2004

Ehlers et al. 2003

Sattenspiel and Herring 2003

Sattenspiel et al. 2000

Severe acute respiratory syndrome

Boulos and Nabih 2004

Rogers and Randolph 2003

Affonso et al. 2004
Geographical mapping of asthmatic epidemiological data in an urban centre

Geographical analysis of the spread of chronic inflammatory diseases

Geographical analysis of clusters of patterns of hospitalization of children and adults presenting asthma episodes in relation to proximity to sources of particulate matter pollution

The geographical differentiation in the prevalence of bronchial tenderness

Geographical variations in the frequency of asthma

The relationship between motor vehicle emissions and the respiratory health system, using a geographic information system to estimate mean daily exposure to PM particulate matter (2.5)

Risk assessment models for estimating out-of-hospital myocardial infarction deaths due to poor geographical access to emergency hospital facilities

Geographic analysis of correlation between respiratory health indicators (acute and chronic bronchitis, pulmonary function) and indigenous culture indices in a sample of the American population

Analysis of social and health surveys to identify the relationship between chronic respiratory diseases and determinants

Pertussis mortality trends are associated with non-lethal cases by age, date and geography

Geographical Investigation of Staphylococcus occurrence and antimicrobial sensitivity.

Geographical survey on the use of pneumocystis carinii pneumoniae

Estimation of GIS mapping using influenza surveillance data

Evaluation of GIS statistical techniques to develop integrated population sampling strategies for surveillance of infectious diseases, especially those originating from birds

Spatial analysis and management of the avian influenza epidemic using GIS systems (VetGIS)

Historical geographical modelling of the spread of the 1918-19 flu epidemic in Canada, with particular reference to whether it has affected human isolation

Historical geographical modelling of the impact of indigenous migration on the spread of the influenza epidemic in 1918-1919

Possibilities of using GIS in predicting the global distribution of infectious diseases

Spatial analysis of the SARS epidemic 
Table 1 (continued)

Asthma

Hantavirus viruses

Fang et al. 2003

Avian influenza

Boulos and Nabih 2004

Bioterrorism

Boulos and Nabih 2004

McLafferty 2003

Ruiz and Remmert 2004

Zubieta et al. 2003

Air pollution

Gilbert et al. 2005

Oyana and Rivers 2005

Oyana et al. 2004

Brun et al. 2004

Climate change

Manfreda et al. 2001

Sauchyn 2001

Socioeconomic characteristics

Baker (2019)

Wilson et al. (2019)

Hospitalization and healthcare

Chen and Ye (2020)

Chen and Pan (2020)

Khashoggi and Murad (2020)

Park et al. (2019)

Yang and Kim (2020)

Zang et al. (2019)

Others

Park and Kwon (2019)
Spatial analysis of haemorrhagic fever distribution

Integration of GIS technology into contingency plans for a possible avian influenza pandemic

Integrate GIS technology into the daily routine of local health services

Application of GIS technology to the investigation of potential carbon exposure

Geospatial analysis of atmospheric concentrations of nitrogen dioxide to assess the epidemiological risks of exposure to air pollution associated with car traffic

Geographical variations in patterns of paediatric asthma care and proximity to sources of environmental pollution

Geospatial analysis of adult asthma care and exposure of residential areas to pollution

Geographical and temporal distribution of polycyclic aromatic hydrocarbons

Variation in the prevalence of asthma symptoms, asthma attacks and the use of asthma medicines between Canada and the international level due to environmental effects

Spatial modelling of landscape sensitivity to climate change

Heat waves and homelessness: analysis of San Diego and Recommendations

Using GIS to advance social economics research: geocoding, aggregation, and spatial thinking

Geographic proximity in the community eldercare community eldercare ecology in China

The effect of spatial access to primary care on potentially avoidable hospitalizations of the elderly: evidence from Chishui City, China

Issues of healthcare planning and GIS: a review

Subsidized housing and geographic accessibility to neighborhood resources for low-income older people: from later year social exclusion perspective

Qualitative study on the perception of community food-accessibility environment among urban older adults

Disentangling residential self-selection from impacts of built environment characteristics on travel behaviors for older adults

Examining the association between socioeconomic status and exposure to carcinogenic emissions in Gyeonggi of South Korea: a multi-level analysis 
Table 1 (continued)

Asthma

Brown et al. (2020)

Mapping place values: 10 lessons from two decades of public participation GIS empirical research

Singh and Taylor (2020)

Assessing and mapping human health risks due to arsenic and socioeconomic correlates for proactive arsenic mitigation arsenic water resources contamination

self-governing regions of Greece and providing such services to elderly according to the Central Union of Municipalities of Greece (2013) are 1110 open elderly care centers, 876 units named "Help at Home", 183 units for social care, and 62 centers of day elderly care. Among them, the open elderly care centers first appeared in 1979 in the form of voluntary organizations supervised by the Greek Ministry of Health and Welfare. They provide services for the elderly in order to avoid their marginalization or institutionalization and to keep their interest in their social context, by self-activation and by increase of the local community interest for them. Therefore, the concept of the open elderly care centers is to keep elderly within their community, family environment, and friendly surroundings and to avoid closed residential care and other forms of hospice. After 1991, their supervision passed from the Ministry of Health and Welfare to the Ministry of Internal Affairs.

Services of open elderly care centers are provided to men and women aged over 60 years living in the surrounding area where they work, regardless of their economic and social situation. Active members of open elderly care centers may not be less than 50 and more than 300 persons. The services provided by the open elderly care centers combine traditional preventive medicine and primary care services, covering the needs of the elderly concerning primary (vaccinations, advice for avoiding accidents) and secondary prevention (medical examinations aimed at early detection). Moreover, the open elderly care centers provide organized entertainment services and participation of older people in various social activities in order to activate them and to keep them as equal members on the community. Meanwhile, the open elderly care centers provide preventive care services for early diagnosis, to avoid long-term therapy.

However, the number of open elderly care centers offering an interesting program of activities internally or in collaboration with other local organizations is small. Usually, the offered activities are limited to the help of some older people at their home and to the organization of excursions, museum visits, watching, or organizing plays.

Specialties of employees in the open elderly care centers are appropriate to the nature of the services provided. They are mainly staffed by doctors of natural medicine, social workers, physiotherapists, occupational therapists, health nurses, and family assistants.

Thus, the main research question is related to the differences and problems created due to the geographical distribution of the elderly population (in urban, semi-urban, and rural areas), their effects on the mental and physical health of the elderly, their creative representation using GIS systems, and the possibility provided by GIS systems for the immediate intervention of the responsible people, in order to solve such problems for the benefit of the elderly. 
Specifically, the following steps have been pursued:

- Recording of the current profile of the elderly in the open elderly care centers

- Investigation of the perception of the health status by elderly

- Investigation of the proportion of older people suffering from health problems

- Investigation of the most common health problems in the elderly

- Investigation of the percentage of elderly whose health status affects their life quality

- Investigation of the overall life quality of elderly

- Investigation of the degree of correlation of socio-economic indicators to the quality of life of elderly

- Investigation of the modulation degree of correlation of socio-economic indicators to the quality of life of elderly, in individual open elderly care centers in Greece included in the survey

\section{Material and Methods}

The current survey is based on a quantitative data method, which enables systematic collection of objective numerical data for statistical use (Mantzoukas 2007), based on a typical sequence of research stages. The quantitative research design is fixed and predetermined (Bellali and Papazoglou 2004).

The questionnaire (see Appendix A) consists of five sections which include 29 questions.

1. The first section is related to the demographic characteristics of the population under study (gender, age, marital status).

2. The second section is related to the characteristics of the residence of the elderly (residence area today, residence area in the past, live, living situation, number of family members living in the same house).

3. The third section deals with the socio-economic characteristics of the elderly (educational level, profession, main source of income, being financial independence, annual income).

4. The fourth section deals with the medical history of elderly (health problems, physical energy, health and reduction in home health and activity, smoking, alcohol, diet, sleep, feeling tired after waking up).

5. Finally, the fifth section is related to how the elderly perceive their quality of life (if they are enjoying their lives, if they are happy for most of the time, if the current economic crisis affects them negatively, if pain affects their welfare, and finally if health problems keep them at home).

Data were collected through questionnaires addressed to the elderly of many open elderly care centers in Greece. Printed questionnaires (Appendix A) were used for participants who did not have access to the Internet. Questionnaires in digital form using python language were answered by participants having access to the Internet, which could be completed easily by elderly with or without the aid of another person. The quantitative approach of the research involves predefined answers in order to facilitate statistical analysis. 
Answered questionnaires were a representative sample of the population under study (Bellali and Papazoglou 2004). Specifically, 897 questionnaires are completed from the following open elderly care centers in Greece as shown in the following table (Table 2):

The survey was carried out between March 2015 and July 2016. All collected data were in coded form to ensure the anonymity of participants. Then, the completed questionnaires were introduced in the electronic database to be processed and analyzed. Descriptive statistics was applied (calculation rates and frequency distributions, central tendency indicators, dispersion) in order to present the study data and to draw conclusions regarding the surveyed population. Specifically, Spearman test was used to test the association of categorical variables. The confidence interval (CI) in which statistical tests were performed was $95 \%$ (i.e., $a=0.05$ ).

Finally, the obtained results were presented in the form of charts for the different regions of Greece, using GIS system, as a mean to visually illustrate socio-economic indicators that affect the health of the elderly, in different geographical positions.

Recognizing that morality and ethics are important parts of our research work, the completion of the questionnaires was done voluntarily by older people. Also, it was known by all participants that the survey was carried out for academic purposes. Therefore, elderly participants experienced the collection of data process in a cooperative way.

On the other hand, the used predefined answers in the questionnaires obviously reduce the degree of honesty of the participants, and this is considered as a limitation of our survey. Also, the existing bureaucracy of the authorities during the license application to carry out the research process is considered as another limitation for the survey.

\section{Results}

\section{Main Demographic, Social, and Economic Data}

Regarding the gender distribution of the participants, $43.3 \%$ (388 participants) of them were men, and $56.7 \%$ (504 participants) of them were women. Generally the age group of 70-80 years represents the relative majority of the participants with a percentage of $40.8 \%$ (see Table 3). Their age distribution is shown in Fig. 1. It is clear that there is a

Table 2 Questionnaires completed from the open elderly care centers in Greece

\begin{tabular}{lc}
\hline Open elderly care centers (City Names) & No of questionnaires \\
\hline Tripoli & 132 \\
Kalamata & 158 \\
Patras & 102 \\
Komotini & 119 \\
Drapetsona-Keratsini & 64 \\
Megalopoli & 92 \\
Neoi Iraklio-Attica & 61 \\
Galatsi-Attica & 116 \\
Rhodes & 53 \\
\hline
\end{tabular}


Table 3 Summarized main demographic, social, and economic data

\begin{tabular}{|c|c|c|c|}
\hline Gender & & $\%$ & \\
\hline Man & & 43.3 & \\
\hline Woman & & 56.7 & \\
\hline Age group & $\%$ & Education level & $\%$ \\
\hline$<70$ years & 34.3 & Without education & 12.2 \\
\hline $70-80$ years & 40.8 & Primary & 40.4 \\
\hline$>80$ years & 24.9 & Secondary & 20.2 \\
\hline Marital status & $\%$ & College & 14.9 \\
\hline Married & 47.7 & Post-college & 4.5 \\
\hline Unmarried & 9.4 & Technological & 1.4 \\
\hline Widowed & 34.7 & University graduate & 5.7 \\
\hline Divorced & 6.5 & Post-graduate & 0.4 \\
\hline Separated & 1.8 & Doctorate & 0.3 \\
\hline Living status & $\%$ & Profession & $\%$ \\
\hline Alone & 32.4 & Unskilled worker & 5.8 \\
\hline Husband/wife or other fellow & 33.1 & Skilled worker & 5.4 \\
\hline Children or grandchildren & 19.8 & Freelance & 14.4 \\
\hline Other relatives & 5.4 & Farmer & 11.1 \\
\hline House assistant & 3.8 & Private employee & 16.5 \\
\hline Professional care & 1.4 & State employee & 22.5 \\
\hline Other & 1.6 & Housekeeping & 22.9 \\
\hline Husband/wife or other fellow and children or grandchildren & 2.3 & Unemployed & 1.4 \\
\hline \multirow{3}{*}{ Husband/wife or other fellow and a professional caregiver } & \multirow{3}{*}{0.1} & Self-financed & $\%$ \\
\hline & & Yes & 75.1 \\
\hline & & No & 24.9 \\
\hline Place of living & $\%$ & Annual income & $\%$ \\
\hline Home & 91.9 & No income & 7.4 \\
\hline Owner & 79.3 & $0-6.000 €$ & 21.9 \\
\hline Rented & 12.6 & $6.001-12.000 €$ & 42.6 \\
\hline Guest & 6.5 & $12.001-24.000 €$ & 24.0 \\
\hline Nursing house & 1.7 & More than $24.000 €$ & 4.2 \\
\hline
\end{tabular}

demographic superiority of women over men in the age groups between 70 and 80 years and less than 70 years, representing $41.5 \%$ and $40.9 \%$ of total, respectively, while in the age group of over 80 years, there is a demographic superiority of men, representing $34.3 \%$ of total compared with $17.7 \%$ of women.

Concerning the marital status of the participants, the majority of them is married, representing $47.7 \%$, while the next largest group, representing $34.7 \%$, are widowed (see Table 3). Only $9.4 \%$ are single, and $6.5 \%$ are divorced, while $1.8 \%$ are leaving separated. Their distribution is shown in Fig. 2. Obviously, there is a demographic superiority of women in the widowed group, representing $40.3 \%$ of total, while there is a demographic superiority of men in the married group, representing the $53.6 \%$ of total.

As it is shown in Table 3, the highest percentage of $33.1 \%$ of elderly in the current survey is living with his wife/partner, and also another high percentage of $32.4 \%$ is 


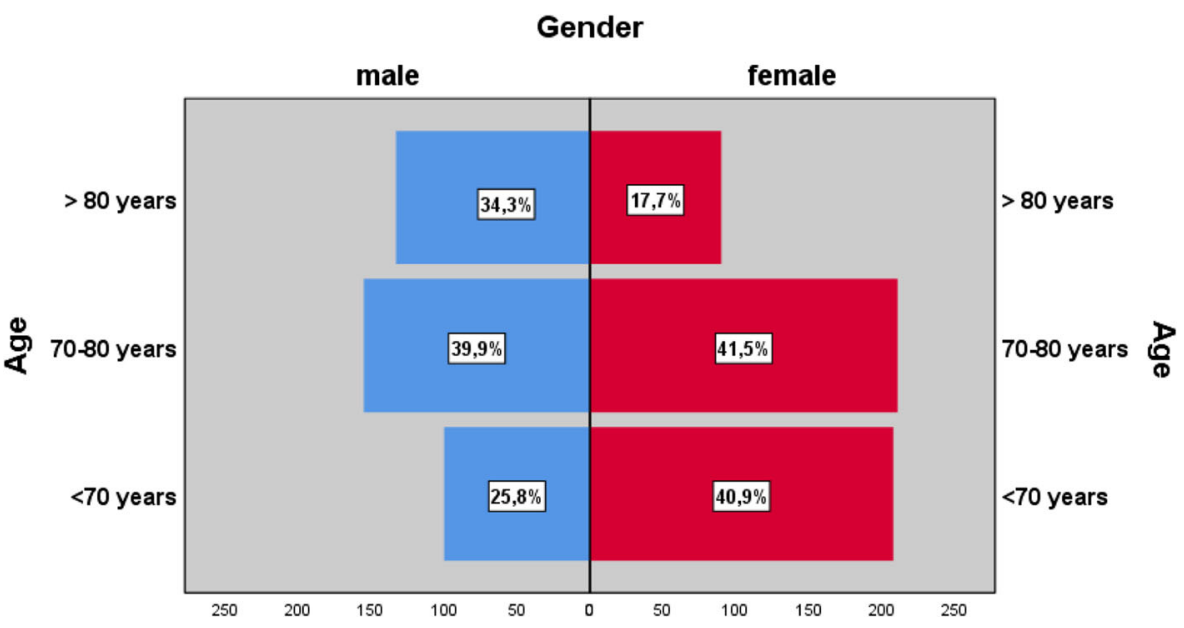

Fig. 1 Age distribution of participants

living alone. A notable percentage of around $19.8 \%$ of participants reported that they stay with children/grandchildren, while at lower percentages of around $5.4 \%, 3.8 \%$, and $1.4 \%$ reported that they live with other relatives, with house assistants, or with a professional caregiver, respectively. A percentage of $91.9 \%$ of participants lives at home, while the rest of them are living as guests or in a nursing house, with percentages $6.5 \%$ and $1.7 \%$, respectively.

As far as the educational level concerns, it is clear that the majority of the participants, with a percentage of $40.4 \%$, has a primary school education level, as shown in Table 3, while those having a secondary school and college educational follow with percentages of around $20.2 \%$ and $14.9 \%$, respectively. It is noteworthy to mention that $12.2 \%$ do not have any kind of education. Smaller percentages of $5.7 \%$ are university graduates, $4.5 \%$ have post-college educational level, and $1.3 \%$ are graduates from

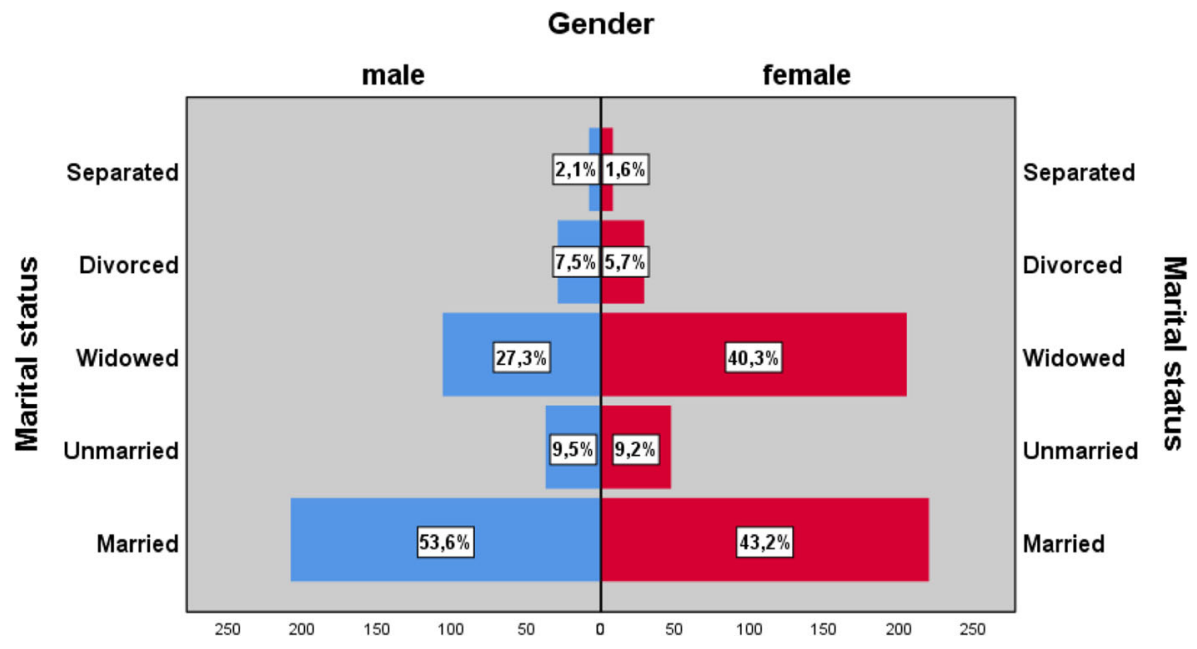

Fig. 2 Marital status of participants 


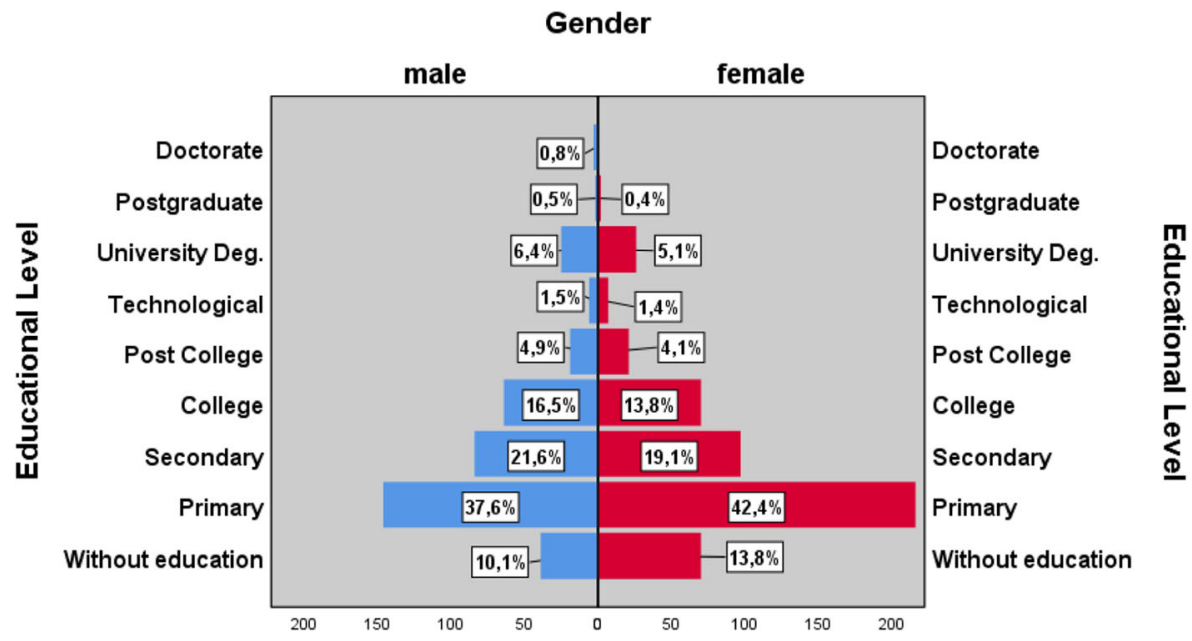

Fig. 3 Education level of participants

technological educational institutes. The distribution of educational level between men and women is shown in Fig. 3.

Concerning the previous profession of the participants, it is clear from Table 3 that housekeeping and state employees were their main professions, with percentages of $22.9 \%$ and $22.5 \%$, respectively, with housekeeping being the main previous profession of women, as shown in Fig. 4. A percentage of $16.5 \%$ of the participants were private employees, $14.4 \%$ were freelancers, and $11.1 \%$ were farmers. Lower percentages of $5.4 \%$ and $5.8 \%$ were skilled and unskilled workers, respectively, while a percentage of $1.4 \%$ declares us unemployed. The distribution of participants' previous profession between men and women is shown in Fig. 4.

Most of the participants, i.e., 75.2\% are self-financed, as shown in Table 3, while a percentage of $42.6 \%$ of them have a yearly income between $6001 €$ and $12,000 €$. Lower percentages of $21.9 \%$ and $24.0 \%$ have yearly income between $0 €$ and $6000 €$ and between $12,001 €$ and $24,000 €$, respectively. A small percentage of 7.4\% declares that they have no income at all, while a smaller percentage of $4.2 \%$ has a yearly income which exceeds $24,000 €$.

\section{Elderly Health, Quality of Life, and Main Health Problems}

The main health problems, according to the current survey, are briefly listed in Table 4, sorted by research area. The most common health problems are hypertension with 274 cases and cardiovascular problems with 202 cases, followed by musculoskeletal/ mobility disabilities with 187 cases, diabetes with 183 cases, vision problems with 151 cases, periodontitis with 147 cases, hearing problems with 138 cases, psychiatric problems with 106 cases, dementia with 99 cases, neurological problems with 77, and finally, trauma injuries with 66 cases.

Moreover, the diagram of Fig. 5 illustrates the results of descriptive statistics about the perceived general health of the participants and particularly (i) the existence of 


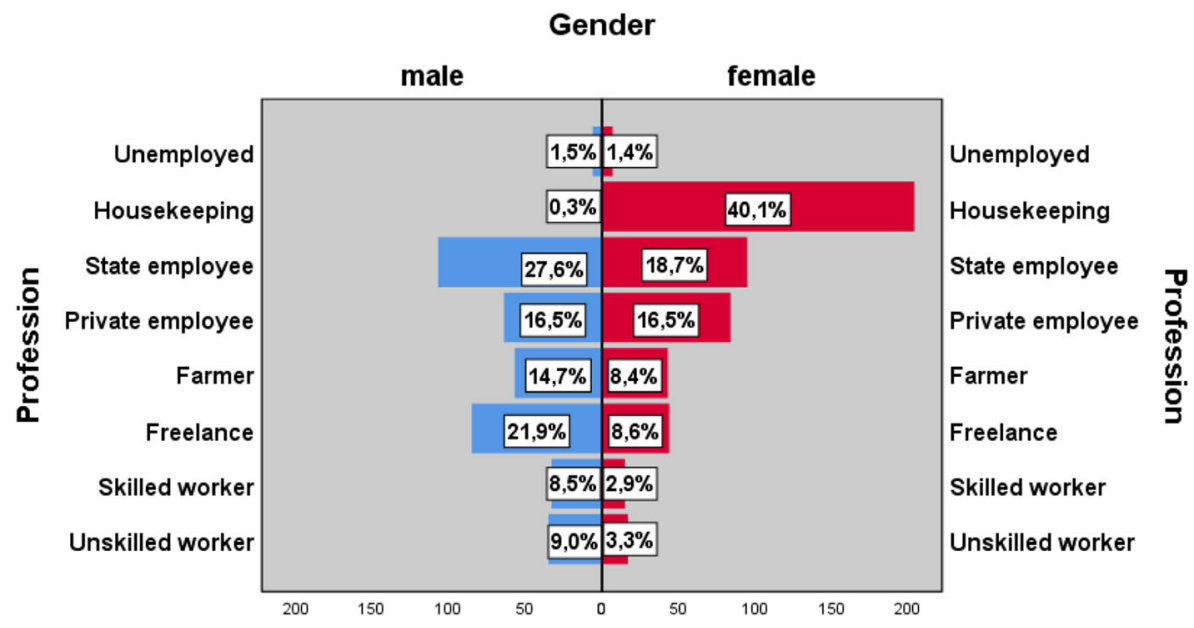

Fig. 4 Previous profession of participants

natural energy, (ii) whether their overall health restricts them to remain home, and (iii) if they consider themselves quite healthy to have some kind of activity. As it can be seen, the majority of participants feels satisfied about their physical energy which disagrees with the view that their health restricts them to remain at home and believes that they are healthy enough to have some sort of activity.

Additionally, the diagram of Fig. 6 presents the results of descriptive statistics about the perceived quality of life of participants and particularly (i) if they generally enjoy their life, (ii) if they are usually happy, (iii) if economic crisis affects their life, and (iv) if they feel healthy enough in order to take part in different activities. It is clear that the majority of elderly participants answered that they generally enjoy their lives and they are usually feel happy. On the other hand, the majority believes that economic crisis affects negatively their life and that pain affects their prosperity (Table 5).

\section{Correlations}

In order to measure the degree of relevance and interaction between two or more variables, the Spearman $(r)$ coefficients have been used which refer to qualitative variables and categorical variables. The values of a correlation coefficient range from -1 to +1 . Negative values mean that there is a negative linear correlation, while positive values mean that there is a positive linear correlation between two variables. These correlations are statistically significant if $p$ value $<.05$.

Regarding the correlation between demographic characteristics and aspects of the quality of life of older people, it was found that (a) elderly under 70s perceive better all aspects of quality of life, if compared with people between 70 and 80 years, who in turn generally live better than those aged over 80. (b) However, there is no statistically acceptable link between the marital status and all the quality of life aspects. 


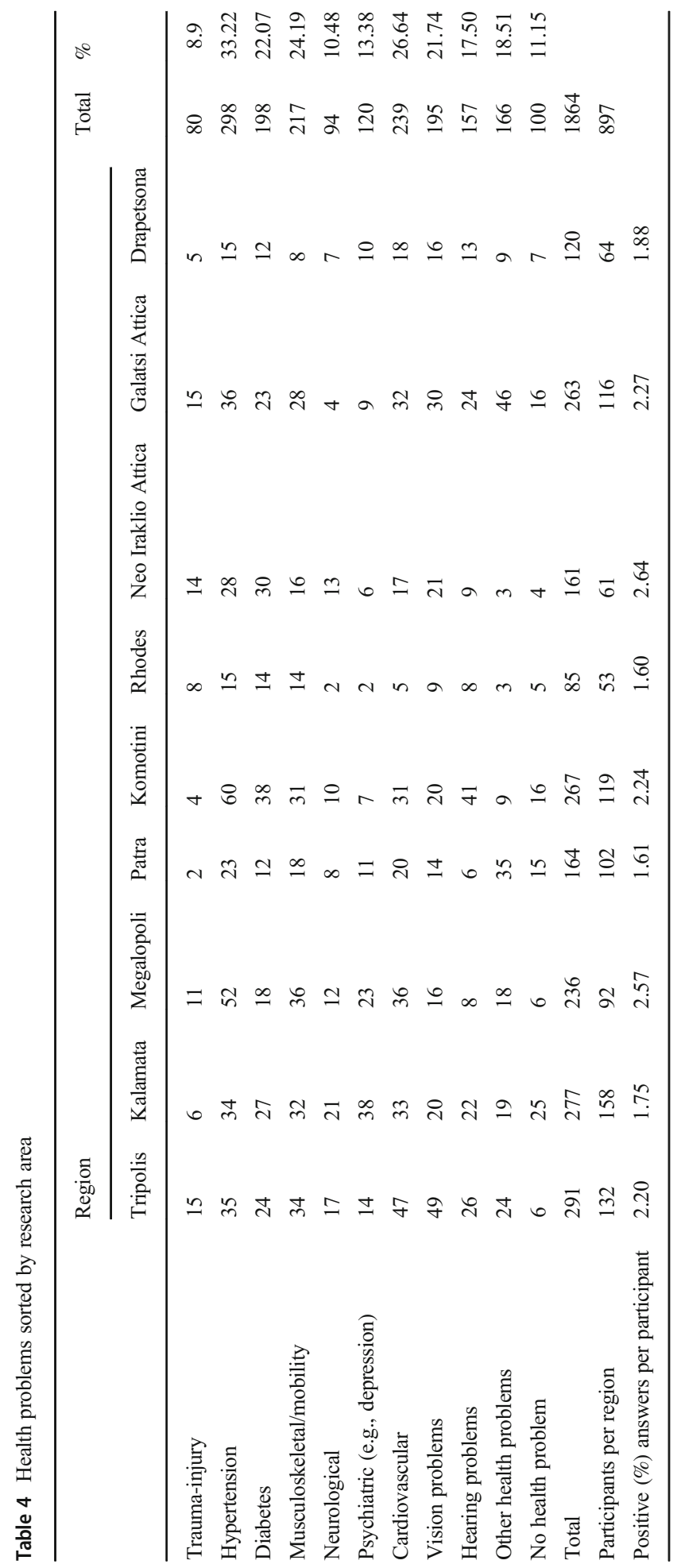




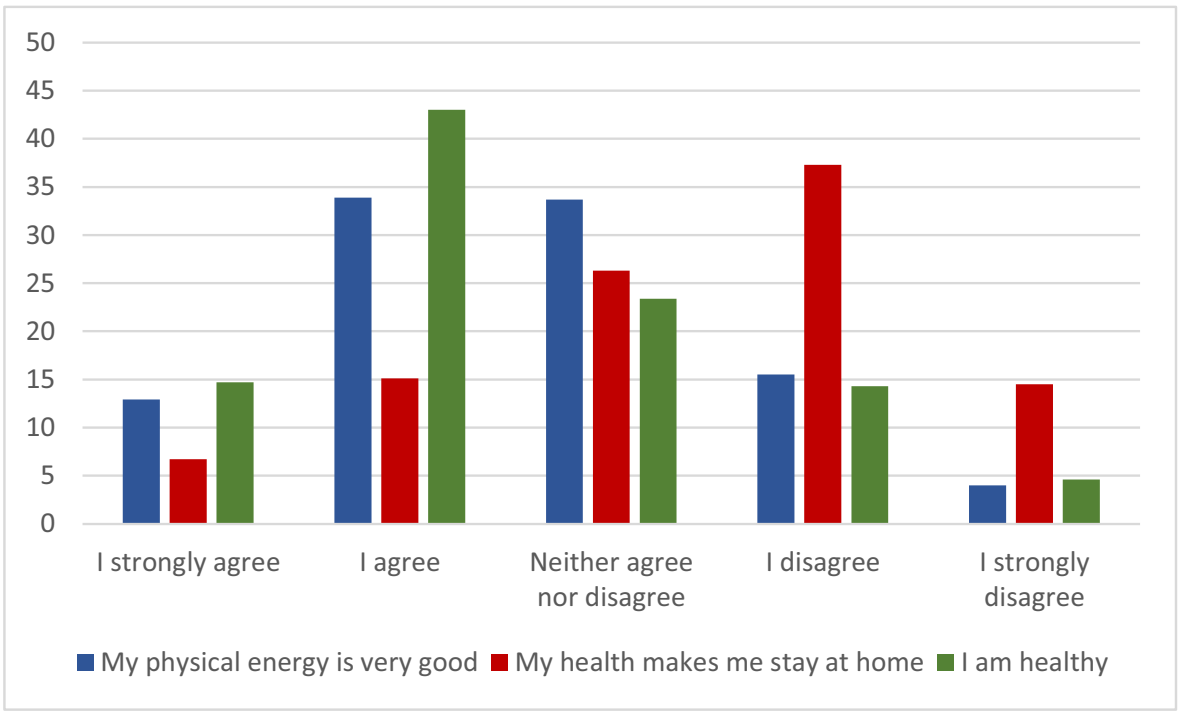

Fig. 5 Perceived general health

Regarding the correlation between social characteristics and quality of life aspects of the elderly, it was found that (a) elderly living in urban areas today perceive better all aspects of quality of life compared with those living in semi-urban areas, which in turn have better quality of life than those living in rural areas. (b) It is confirmed that elderly living in urban areas in the past perceive better all aspects of quality of life compared with those living in semi-urban areas, which in turn have better quality of life than those living in rural areas. (c) It is confirmed that holders of higher education qualifications have generally a better quality of live compared with those with lower education qualifications.

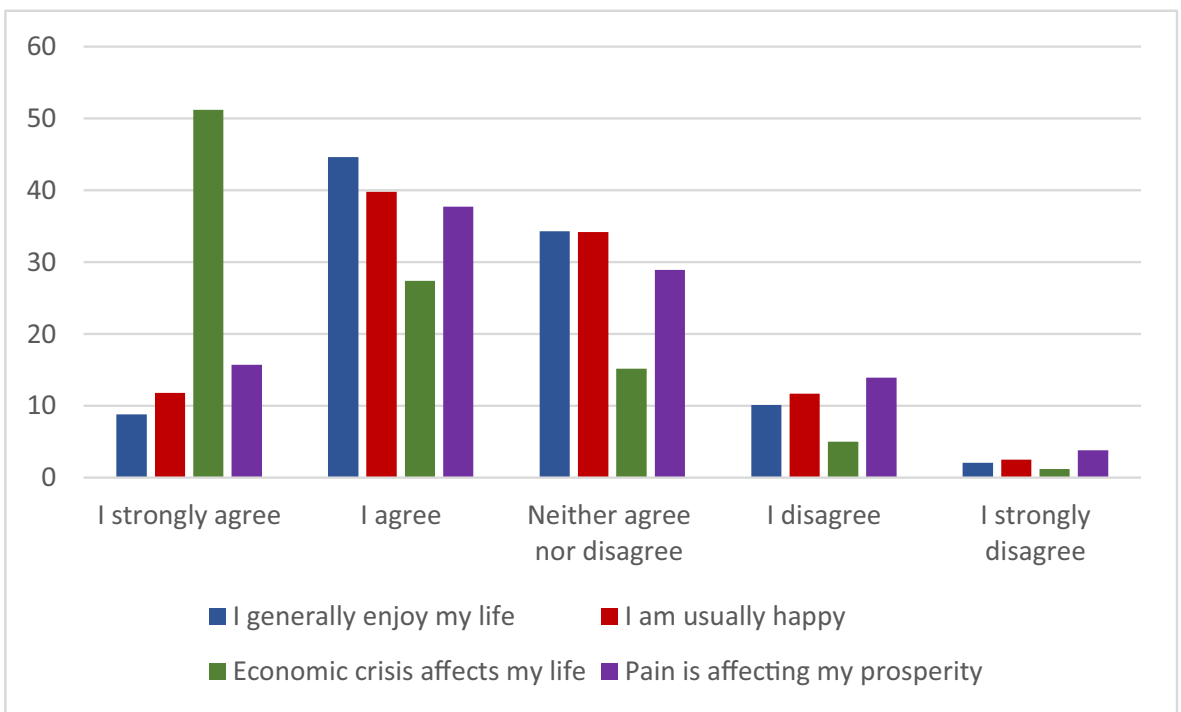

Fig. 6 Quality of life 
Table 5 Spearman correlation of demographic, social, economic, and health factors with several aspects of quality of life

\begin{tabular}{|c|c|c|c|c|c|}
\hline & & & $\begin{array}{l}\text { Quality } \\
\text { of life }\end{array}$ & $\begin{array}{l}\text { Enjoying } \\
\text { life }\end{array}$ & $\begin{array}{l}\text { Mostly } \\
\text { feel } \\
\text { happy }\end{array}$ \\
\hline \multirow[t]{4}{*}{ Demographic } & \multirow[t]{2}{*}{ Age } & $r$ & .202 & .180 & .161 \\
\hline & & $p$ value & .000 & .000 & .000 \\
\hline & \multirow[t]{2}{*}{ Marital status } & $r$ & .033 & .043 & .055 \\
\hline & & $p$ value & .318 & .194 & .098 \\
\hline \multirow[t]{6}{*}{ Social } & \multirow[t]{2}{*}{ Current place of residence } & $r$ & .230 & .186 & .223 \\
\hline & & $p$ value & .000 & .000 & .000 \\
\hline & \multirow{2}{*}{$\begin{array}{r}\text { Previous place } \\
\text { of residence }\end{array}$} & $r$ & .153 & .126 & .167 \\
\hline & & $p$ value & .000 & .000 & .000 \\
\hline & \multirow[t]{2}{*}{ Educational level } & $r$ & .169 & .177 & .168 \\
\hline & & $p$ value & .000 & .000 & .000 \\
\hline \multirow[t]{6}{*}{ Economic } & \multirow[t]{2}{*}{ Self-financed } & $r$ & .226 & .171 & .184 \\
\hline & & $p$ value & .000 & .000 & .000 \\
\hline & \multirow[t]{2}{*}{ Yearly income } & $r$ & .244 & .211 & .246 \\
\hline & & $p$ value & .000 & .000 & .000 \\
\hline & \multirow[t]{2}{*}{ Effect of economic crisis } & $r$ & .145 & .096 & .039 \\
\hline & & $p$ value & .000 & .004 & .242 \\
\hline \multirow[t]{8}{*}{ Medical } & \multirow{2}{*}{$\begin{array}{l}\text { I feel healthy enough in } \\
\text { order to be active }\end{array}$} & $r$ & .476 & .541 & .451 \\
\hline & & $p$ value & .000 & .000 & .000 \\
\hline & \multirow{2}{*}{$\begin{array}{l}\text { I have very good } \\
\text { physical energy }\end{array}$} & $r$ & .567 & .603 & .530 \\
\hline & & $p$ value & .000 & .000 & .000 \\
\hline & \multirow{2}{*}{$\begin{array}{l}\text { I suffer from pain that } \\
\text { affects my well-being }\end{array}$} & $r$ & -.301 & -.260 & -.235 \\
\hline & & $p$ value & .000 & .000 & .000 \\
\hline & \multirow[t]{2}{*}{ My health confines me home } & $r$ & -.303 & -.315 & -.256 \\
\hline & & $p$ value & .000 & .000 & .000 \\
\hline
\end{tabular}

Concerning the correlation between economic characteristics and quality of life aspects of the elderly, it was found that (a) elderly with self-financing ability have generally a better quality of live compared with those without financial selfreliance. (b) It was confirmed that elderly with highest annual income perceive better all aspects of quality of life compared with those with lower annual income. (c) Those who feel that they are not affected by the economic crisis have a better quality of life and feel that they are enjoying life. However, the perception of the current economic crisis is not statistically correlated with the sense of happiness for most of the time.

Regarding the existence of correlations between health characteristics and quality of life aspects of the elderly, it was found that (a) it was confirmed that elderly feeling healthy enough in order to be active perceive generally a better quality of life compared with those who do not feel health enough. (b) Elderly who have a good physical energy 
have generally a better quality of life than those who do not have a good physical condition. (c) Elderly suffering from pain have generally a worse quality of live, compared with those without pain. (d) Elderly having health problems confining them to home perceive generally a worse quality of life compared with those who are not confined to home for health reasons.

There is almost complete coincidence of our research findings and their statistical analysis with the theoretical approaches of the related literature, with the exception of the case of the marital status of the elderly and the assumption that married, widowed, divorced, and, finally, unmarried persons have better quality of life by this order. We could not find a statistically acceptable relationship, probably due to the type and size of the sample. It also appears that the sense of happiness of the elderly in most of the time is not exclusively related to the effects of the economic crisis, possibly due to the type and size of the sample.

\section{GIS Presentation}

The results of the current survey, concerning the location of certain health problems and aspects of perceived general health and perceived quality of life of participants, are located automatically in geographic maps as geographic information systems (GIS), in order to be shared and analyzed easily. These systems could provide quick information to other researchers, state employees, and responsible politicians, taking critical decisions for the health of elderly. Some examples are given in the following Figs. 7, 8, 9, and 10.

\section{Conclusions and Recommendations}

A sample of 897 questionnaires, collected from a number of open elderly care centers in Greece, was the basis of the current survey. There is almost complete coincidence of our research findings and their statistical analysis with the theoretical approaches of the related literature, with the exception of the relation of marital status with the perception of the quality of life.

The research findings and their statistical analysis show a complete agreement with the existing theoretical bibliographic approaches, with the exception of the theoretically reported correlation between the best quality of life and married life, probably due to the type and size of the sample. Furthermore, it was found that the elderly's sense of happiness is often not solely related to the effects of the financial crisis, possibly due to the type and size of the sample.

The results, concerning the location of certain health problems and aspects of perceived general health and perceived quality of life of participants, were located automatically in geographic maps as geographic information systems (GIS), in order to be shared and analyzed easily. Creating a means to illustrate socio-economic indicators that affect the health of the elderly, according to their geographical position, will provide health service providers a key instrument to make informed decisions in managing and resolving the problems faced by the elderly, either in providing socioeconomic or medical help. 

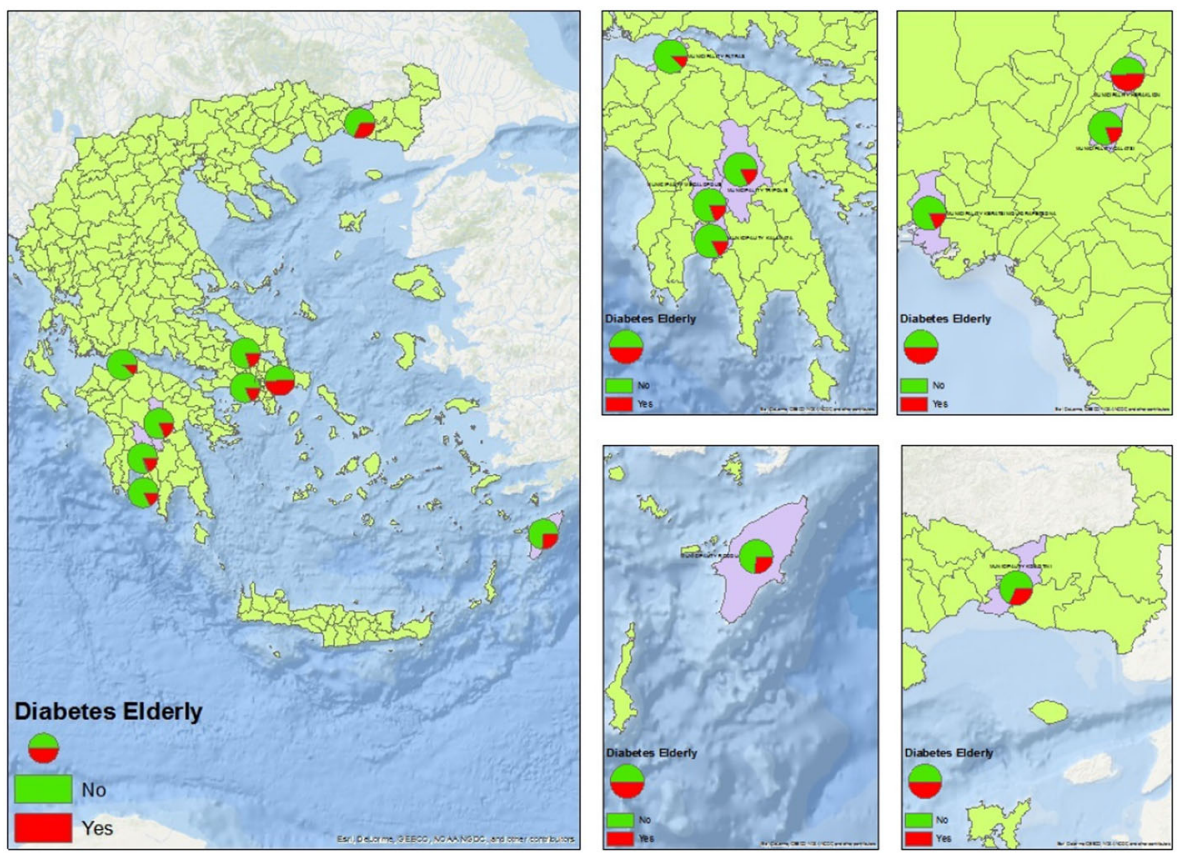

Fig. 7 Map of diabetes, showing the higher number of cases in urban areas and northern Greece
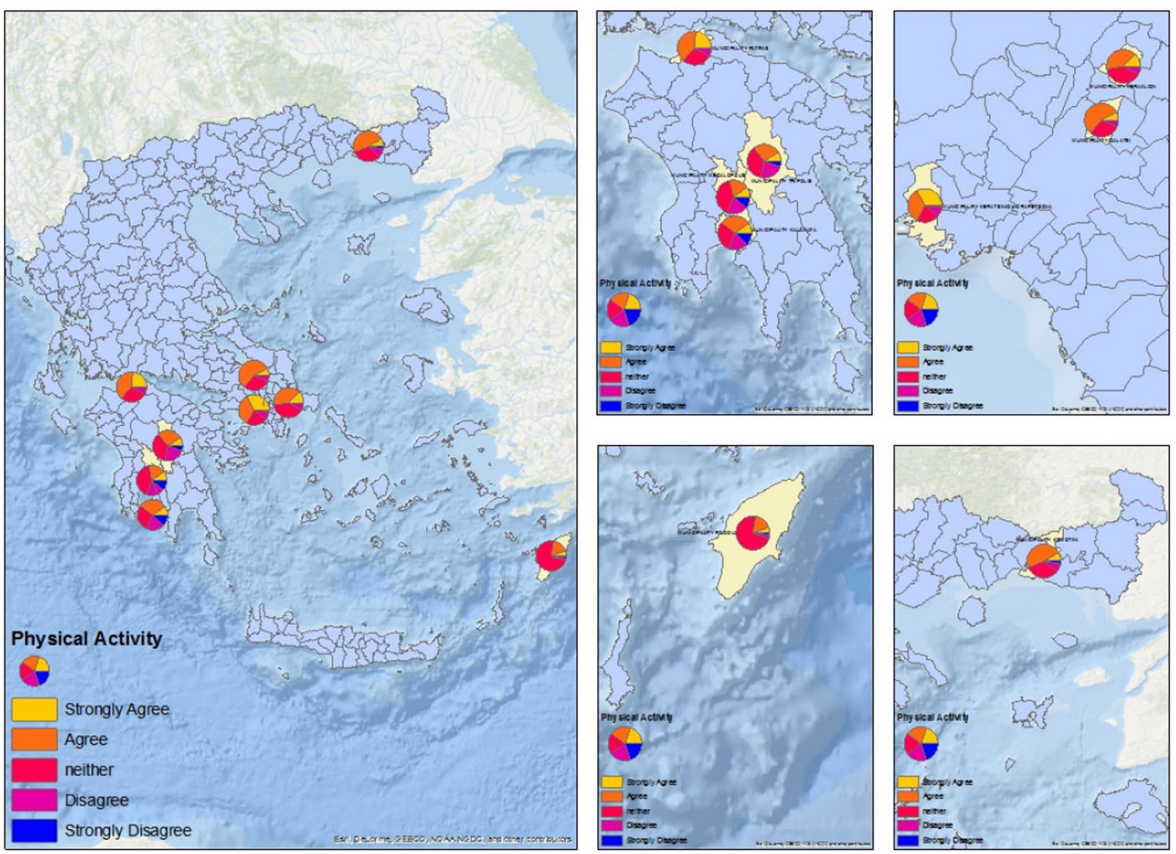

Fig. 8 Map of physical activity showing that people living in urban areas with better healthcare believe that they have better physical condition than those living in rural areas where people has been involved in manual work for a long time 

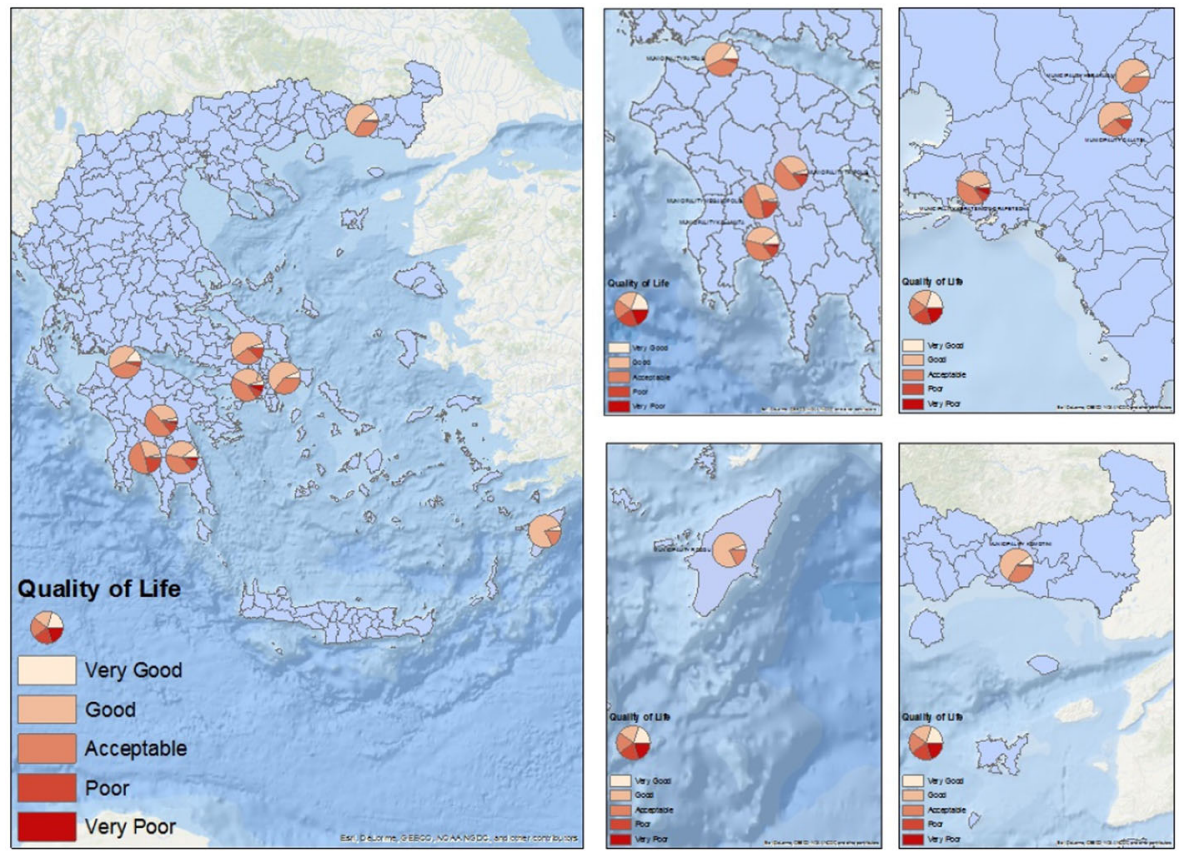

Fig. 9 Map of quality of life showing that people living in urban areas believe that they have a higher level of quality of life
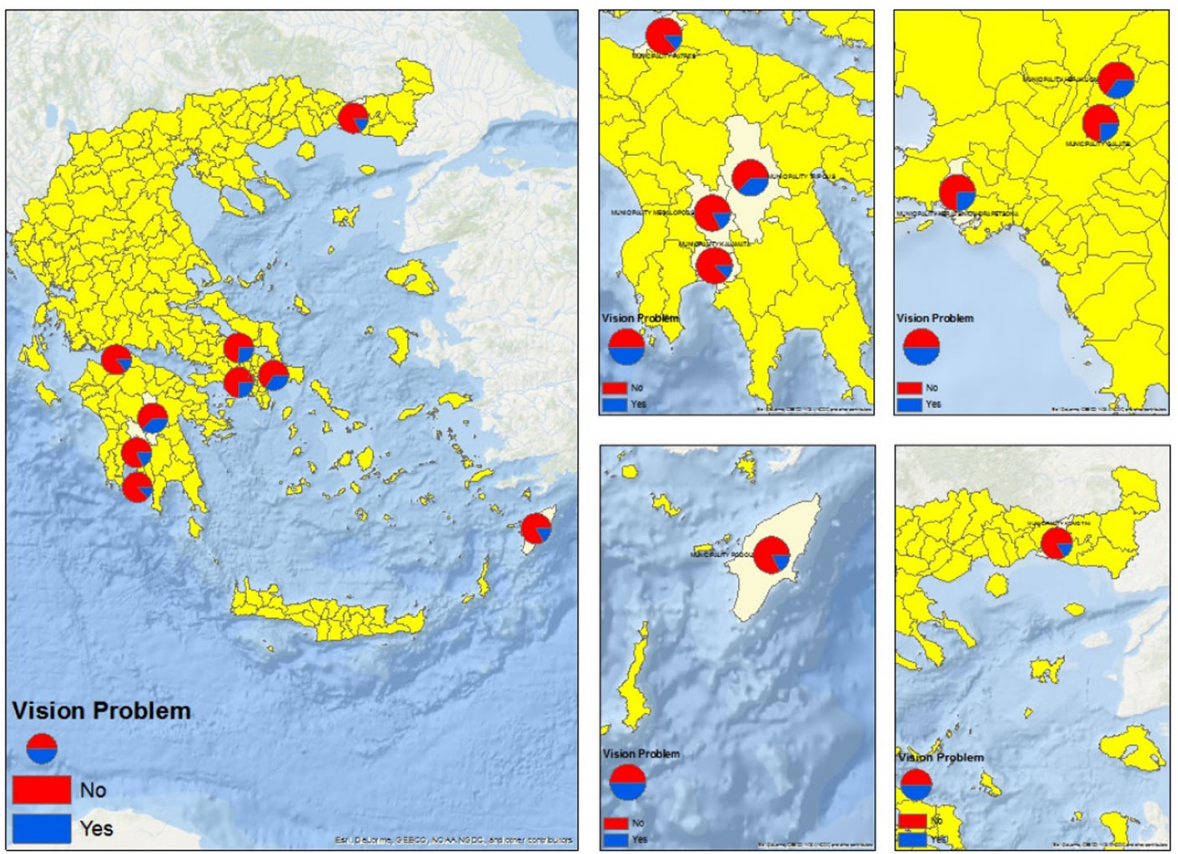

Fig. 10 Map of vision problems showing that people living in rural areas have lower vision problems due to a better field of view 
The limitations of the research were more bureaucratic in terms of issuing each license. Another limitation has been the difficulty of completing the electronic questionnaire over the printed questionnaire, since it is addressed to older people who are not so familiar with new technologies and computers. Another problem was the relative difficulty in understanding some of the questions in the questionnaire by some older people, mainly because of their age.

The quality and accuracy of the survey largely depends on the honesty of the respondents. Furthermore, funding is needed to enable the research sample to be expanded and a sufficient number of researchers involved. The lack of funding for such researches makes their implementation difficult, while the training of responsible staff to acquire the appropriate information and mentality is limited.

In addition, it is necessary to enable public officials to have access to the data of such surveys, in order to make them useful in finding immediate solutions whenever needed. Additionally, the absence of a general information network for the existing problems of the elderly due to their geographical distribution makes such researches less adapted to the regional characteristics of the elderly lifestyle.

It is proposed for the overall treatment of the elderly patient that there should be subsystems capable of communicating and exchanging information, under the supervision of a centralized management. By this way, the elderly patient will be able to have the appropriate services in time and at the required place. The required data for decision-making and strategy-setting must be uniform, so it is necessary to specify standards and define a specific methodology for capturing and storing data through GIS.

Given the usefulness of research in the field of health, and in particular in capturing the health problems of the elderly, it is also recommended to extend the research to other countries, notably the European Union, for the purpose of broader data collection and evaluation and comparative reporting of data and surveys of the EU member states.

Moreover, the use of GIS systems should be extended to include more geographically distributed data on endemic diseases and pandemics, such as the recent Covid19 pandemic, facilitating rapid conclusions about their transmission and the required traceability.

\section{Compliance with Ethical Standards}

Conflict of Interest The authors declare that they have no conflict of interest.

Research Involving Human Participants and/or Animals There are not any specific identifiable information for human participants and/or animals.

Informed Consent Informed consent is given for the paper.

Data Availability Our manuscript contains data, which will be made available on reasonable request 


\section{Appendix: Questionnaire}

\begin{tabular}{|c|c|}
\hline \multicolumn{2}{|c|}{ Date: } \\
\hline \multicolumn{2}{|c|}{ City: } \\
\hline \multicolumn{2}{|c|}{ Open Elderly Care Centre: } \\
\hline \multicolumn{2}{|l|}{ A. DEMOGRAPHIC DATA } \\
\hline 1. Gender & $\begin{array}{l}\text { 1. Male } \\
\text { 2. Female }\end{array}$ \\
\hline 2. Age & $\begin{array}{ll}\text { 1. } & <70 \\
\text { 2. } & 70-80 \\
\text { 3. } & >80\end{array}$ \\
\hline 3. Marital status & $\begin{array}{ll}\text { 1. } & \text { Married } \\
\text { 2. } & \text { Unmarried } \\
\text { 3. } & \text { Widow } \\
\text { 4. } & \text { Divorced } \\
\text { 5. } & \text { Separated } \\
\end{array}$ \\
\hline \multicolumn{2}{|l|}{ B. RESIDENCE } \\
\hline 4. Place of living today & $\begin{array}{ll}\text { 1. Urban }>10,000 \\
\text { 2. Semi-urban } 2,000-10,000 \\
\text { 3. Rural }<2,000\end{array}$ \\
\hline 5. Place of living in the past & $\begin{array}{l}\text { 1. Urban }>10,000 \\
\text { 2. Semi-urban } 2,000-10,000 \\
\text { 3. }\end{array}$ \\
\hline 6. Living in & $\begin{array}{l}\text { 1. House } \\
\text { a. Owner } \\
\text { b. Rented } \\
\text { 2. Guest } \\
\text { 3. Nursing home } \\
\text { (if "yes" then mention the time period): }\end{array}$ \\
\hline \begin{tabular}{|l|} 
7. Living status \\
\end{tabular} & $\begin{array}{l}\text { 1. Living alone } \\
\text { 2. Living with husband/wife or other fellow } \\
\text { 3. Living with children or grandchildren } \\
\text { 4. Living with other relatives } \\
\text { 5. Living with a housekeeper } \\
\text { 6. Living with professional carer } \\
\text { 7. Other }\end{array}$ \\
\hline $\begin{array}{l}\text { 8. Total number of persons } \\
\text { living in the same house }\end{array}$ & Number of persons \\
\hline \multicolumn{2}{|l|}{ C. SOCIAL-ECONOMIC SITUATION } \\
\hline 9. Education & $\begin{array}{l}\text { 1. No education } \\
\text { 2. Elementary school Degree } \\
\text { 3. Secondary school Degree } \\
\text { 4. High School Degree } \\
\text { 5. Post High School Degree } \\
\text { 6. Technological Educational Inst. Degree } \\
\text { 7. First University Degree } \\
\text { 8. Postgraduate Degree } \\
\text { 9. Doctorate Degree }\end{array}$ \\
\hline $\begin{array}{l}\text { 10. Profession (current or } \\
\text { previous in the case of retired) }\end{array}$ & $\begin{array}{l}\text { 1. Unskilled worker } \\
\text { 2. Skilled worker } \\
\text { 3. Freelance } \\
\text { 4. Farmer } \\
\text { 5. Private employee } \\
\text { 6. State employee } \\
\text { 7. House keeper } \\
\text { 8. Unemployed }\end{array}$ \\
\hline 11. Main income source & $\begin{array}{l}\text { 1. Personal Pension } \\
\text { 2. Pension of Husband/Wife } \\
\text { 3. Personal work } \\
\text { 4. Work of Husband/Wife } \\
\text { 5. Family } \\
\text { 6. Personal property } \\
\text { 7. Other }\end{array}$ \\
\hline
\end{tabular}




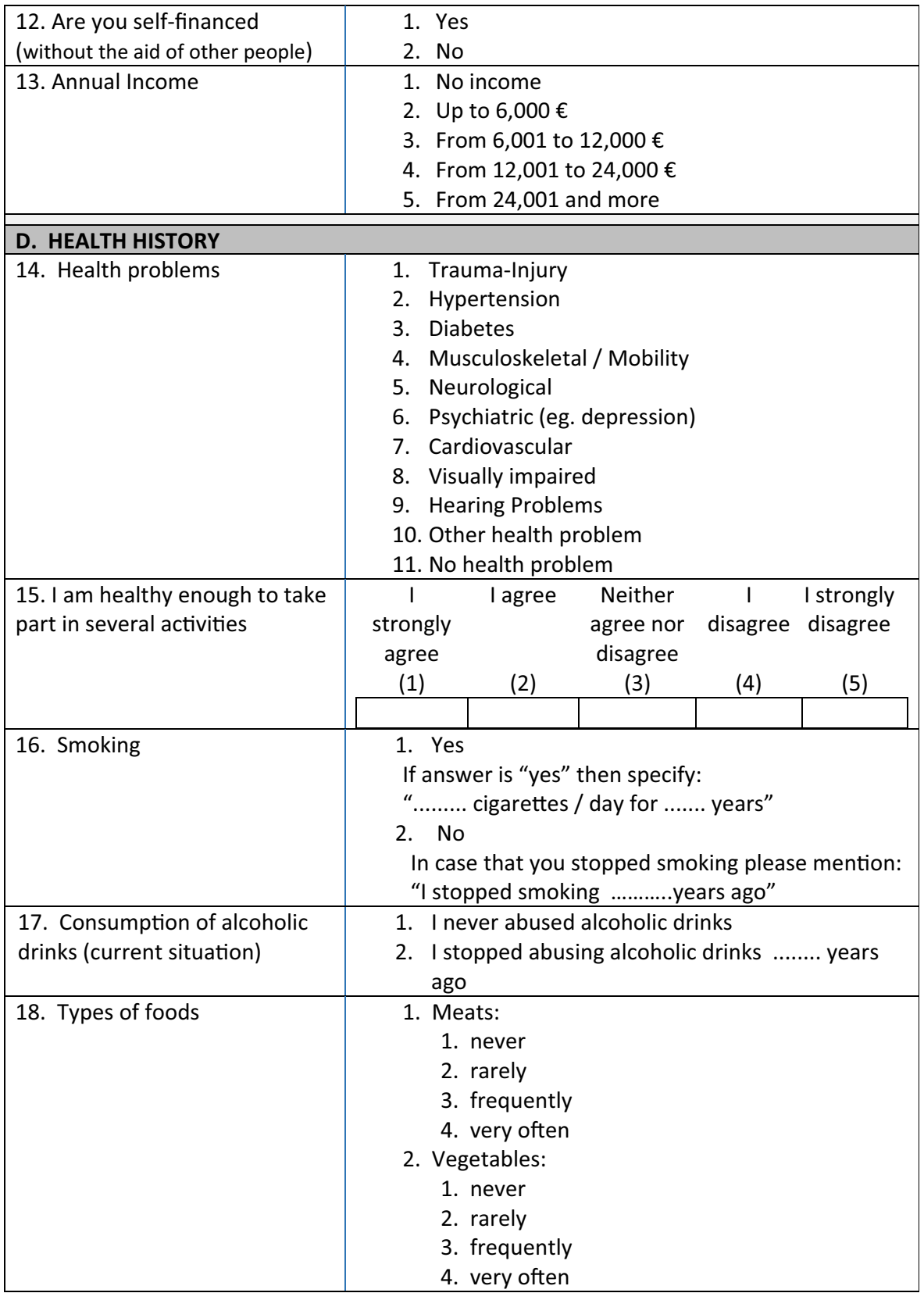




\begin{tabular}{|c|c|c|c|c|c|}
\hline \multirow[t]{2}{*}{$\begin{array}{l}\text { 19. I sleep good (sleeping } \\
\text { quality) }\end{array}$} & \multicolumn{5}{|c|}{$\begin{array}{l}\text { 1. Yes (I sleep easily) } \\
\text { 2. No (I can't sleep easily) } \\
\text { If the answer is No please specify if you are taking } \\
\text { any drug to facilitate sleep }\end{array}$} \\
\hline & $\begin{array}{l}\text { Yes } \\
\text { No }\end{array}$ & & & & \\
\hline 20. I feel tired when I wake-up & \multicolumn{5}{|c|}{$\begin{array}{l}\text { 1. Yes } \\
\text { 2. No } \\
\text { 3. Sometimes } \\
\text { 4. I don't know }\end{array}$} \\
\hline $\begin{array}{l}\text { 21. My physical energy is very } \\
\text { good }\end{array}$ & $\begin{array}{l}\text { I } \\
\text { strongly } \\
\text { agree } \\
\text { (1) }\end{array}$ & $\begin{array}{l}\text { I agree } \\
\text { (2) }\end{array}$ & $\begin{array}{l}\text { Neither } \\
\text { agree nor } \\
\text { disagree } \\
\text { (3) }\end{array}$ & $\begin{array}{c}\text { I } \\
\text { disagree } \\
\text { (4) }\end{array}$ & $\begin{array}{l}\text { I strongly } \\
\text { disagree } \\
\text { (5) }\end{array}$ \\
\hline \multicolumn{6}{|l|}{ E. QUALITY OF LIFE } \\
\hline 22. My life quality is: & $\begin{array}{l}\text { Very } \\
\text { good } \\
(1)\end{array}$ & $\begin{array}{c}\text { Good } \\
(2) \\
\end{array}$ & $\begin{array}{c}\text { Acceptable } \\
\text { (3) }\end{array}$ & $\begin{array}{l}\text { Poor } \\
\text { (4) }\end{array}$ & $\begin{array}{l}\text { Very } \\
\text { Poor } \\
(5)\end{array}$ \\
\hline 23. I generally enjoy my life & $\begin{array}{c}\text { I } \\
\text { strongly } \\
\text { agree } \\
\text { (1) }\end{array}$ & (2) & $\begin{array}{l}\text { Neither } \\
\text { agree } \\
\text { nor } \\
\text { disagree } \\
\text { (3) }\end{array}$ & $\begin{array}{c}\text { I } \\
\text { disagree } \\
\text { (4) }\end{array}$ & $\begin{array}{c}\text { I strongly } \\
\text { disagree } \\
\text { (5) }\end{array}$ \\
\hline 24. I am usually happy & $\begin{array}{c}\text { I } \\
\text { strongly } \\
\text { agree } \\
\text { (1) }\end{array}$ & (2) & $\begin{array}{l}\text { Neither } \\
\text { agree } \\
\text { nor } \\
\text { disagree } \\
\text { (3) }\end{array}$ & $\begin{array}{c}\text { I } \\
\text { disagree } \\
\text { (4) }\end{array}$ & $\begin{array}{c}\text { I strongly } \\
\text { disagree } \\
\text { (5) }\end{array}$ \\
\hline $\begin{array}{l}25 . \text { The current economic crisis } \\
\text { affects my life negatively }\end{array}$ & $\begin{array}{c}\text { I } \\
\text { strongly } \\
\text { agree } \\
\text { (1) }\end{array}$ & I agree & $\begin{array}{l}\text { Neither } \\
\text { agree } \\
\text { nor } \\
\text { disagree } \\
\text { (3) }\end{array}$ & $\begin{array}{c}\text { I } \\
\text { disagree }\end{array}$ & $\begin{array}{c}\text { I strongly } \\
\text { disagree } \\
\text { (5) }\end{array}$ \\
\hline $\begin{array}{l}\text { 26. Pain is affecting my } \\
\text { prosperity }\end{array}$ & $\begin{array}{c}\text { I } \\
\text { strongly } \\
\text { agree } \\
\text { (1) }\end{array}$ & I agree & $\begin{array}{l}\text { Neither } \\
\text { agree } \\
\text { nor } \\
\text { disagree } \\
\text { (3) }\end{array}$ & $\begin{array}{c}\text { I } \\
\text { disagree }\end{array}$ & $\begin{array}{c}\text { I strongly } \\
\text { disagree } \\
\text { (5) }\end{array}$ \\
\hline $\begin{array}{l}\text { 27. My health makes me stay at } \\
\text { home }\end{array}$ & $\begin{array}{c}\text { I } \\
\text { strongly } \\
\text { agree } \\
\text { (1) }\end{array}$ & I agree & $\begin{array}{l}\text { Neither } \\
\text { agree } \\
\text { nor } \\
\text { disagree } \\
\text { (3) }\end{array}$ & $\begin{array}{c}\text { I } \\
\text { disagree }\end{array}$ & $\begin{array}{c}\text { I strongly } \\
\text { disagree } \\
\text { (5) }\end{array}$ \\
\hline
\end{tabular}




\section{References}

Affonso, D. D., Andrews, G. J., \& Jeffs, L. (2004). The urban geography of SARS: Paradoxes and dilemmas in Toronto's health care. Journal of Advanced Nursing, 45(6), 568-578.

Baker, M. (2019). Heat waves and homelessness: Analysis of San Diego and Recommendations.

Bellali, T., \& Papazoglou, E. (2004). Qualitative methodology in nursing research. Nursing, 43, 261-270.

Bernstein, C. N., Wajda, A., \& Blanchard, J. F. (2005). The clustering of other chronic inflammatory diseases in inflammatory Bowel disease: A population-based study. Gastroenterology, 129(3), 827-836.

Börsch-Supan, A., \& Jürges H. (2005). The survey of health, aging, and retirement in Europe. Methodology. Mannheim: Mannheim Research Institute for the Economics of Aging (MEA).

Börsch-Supan A., Brugiavini A., Jürges H., Kapteyn A., Mackenbach J., Siegrist J. \& Guglielmo W. 2008. First results from the survey of health. Ageing. Available in: http://www.share-project.org/t3/share/ uploads/tx_sharepublications/BuchSHAREganz250808.pdf

Boulos, K., \& Nabih, M. (2004). Towards evidence-based, GIS-driven national spatial health information infrastructure and surveillance services in the United Kingdom. International Journal of Health Geographics, 3(1), 1.

Brown, G., Reed, P., \& Raymond, C. M. (2020). Mapping place values: 10 lessons from two decades of public participation GIS empirical research. Applied Geography, 116, 102156.

Brun, G. L., Vaidya, O. C., \& Leger, M. G. (2004). Atmospheric deposition of polycyclic aromatic hydrocarbons to Atlantic Canada: geographic and temporal distributions and trends 1980-2001. Environmental Science \& Technology, 38(7), 1941-1948 Manfreda etal., 2001.

Buckeridge, D. L., Glazier, R., Harvey, B. J., Escobar, M., Amrhein, C., \& Frank, J. (2002). Effect of motor vehicle emissions on respiratory health in an urban area. Environmental Health Perspectives, 110(3), 293-300.

Carone, G., \& Costello, D. (2006). Can Europe afford to grow old? Finance and Development, 43(3), 1-9.

Central Union of Municipalities of Greece (2013). Minutes of Ordinary Congress. Ioannina, 30-31May. $1^{\text {st }}$ Day.

Chen, T., \& Pan, J. (2020). The effect of spatial access to primary care on potentially avoidable hospitalizations of the elderly: Evidence from Chishui City, China. Social Indicators Research, 1-21.

Chen, L., \& Ye, M. (2020). Geographic proximity in the community eldercare community eldercare ecology in China (pp. 85-116): Springer.

Diekema, D. J., Pfaller, M. A., Schmitz, F. J., Smayevsky, J., Bell, J., Jones, R. N., \& Beach, M. (2001). Survey of infections due to species: Frequency of occurrence and antimicrobial susceptibility of isolates collected in the United States, Canada, Latin America, Europe, and the Western Pacific region for the SENTRY antimicrobial surveillance program, 1997-1999. Clinical Infectious Diseases, 32(s2), S114 S132.

Ehlers, M., Möller, M., Marangon, S., \& Ferre, N. (2003). The use of Geographic Information System (GIS) in the frame of the contingency plan implemented during the 1999-2001 Avian Influenza (AI) epidemic in Italy. Avian Diseases, 47(s3), 1010-1014.

Fang, L. Q., Cao, W. C., Chen, H. X., Wang, B. G., Wu, X. M., Yang, H., \& Zhang, X. T. (2003). "Study on the application of geographic information system in spatial distribution of hemorrhage fever with renal syndrome in China" [in Chinese]. Zhonghua Liu Xing Bing Xue Za Zhi, 24(4), 265-268.

Foggin, P. M., \& Aurillon, N. (1989). Respiratory health indicators and acculturation among the Inuit and Cree of northern Quebec: a regional approach using geographic seriation analysis. Social Science \& Medicine, 29(5), 617-626 Levesque et al., 1998.

Gilbert, N. L., Goldberg, M. S., Beckerman, B., Brook, J. R., \& Jerrett, M. (2005). Assessing spatial variability of ambient nitrogen dioxide in Montreal, Canada, with a land-use regression model. Journal of the Air \& Waste Management Association, 55(8), 1059-1063 Oyana \& Rivers 2005.

Habbick, B. F., Pizzichini, M. M., Taylor, B., Rennie, D., Senthilselvan, A., \& Sears, M. R. (1999). Prevalence of asthma, rhinitis and eczema among children in 2 Canadian cities: The international study of asthma and allergies in childhood. Canadian Medical Association Journal, 160(13), 1824-1828 Buckeridge etal., 2002.

Harcourt, S. E., Edwards, D. E., Fleming, D. M., Smith, R. L., \& Smith, G. E. (2004). How representative is the population covered by the RCGP spotter practice scheme? Using geographical information systems to assess. Journal of Public Health (Oxford, England), 26(1), 88-94 Ehlers et al., 2003.

Kapteyn A. (2008). "Comparison between SHARE, ELSA, and HRS”, in: Börsch-Supan A., Brugiavini A., Jürges H., Kapteyn A., Mackenbach J., Siegrist J. \& Guglielmo W. 2008. First Results from the Survey of 
Health, Ageing and Retirement in Europe (2004-2007). Starting the Longitudinal Dimension. Available in: http://www.share-project.org/t3/share/uploads/tx_sharepublications/BuchSHAREganz250808.pdf

Khashoggi, B. F., \& Murad, A. (2020). Issues of healthcare planning and GIS: a review. ISPRS International Journal of Geo-Information, 9(6), 352.

Levesque, B., Lajoie, P., Rhainds, M., Kosatsky, T., Grenier, A. M., Ernst, P., \& Audet, N. (1998). “Quebec social and health survey: Determinants of chronic respiratory diseases", [in French]. Canadian Journal of Public Health, 92(3), 228-232.

Manfreda, J., Becklake, M. R., Sears, M. R., Chan-Yeung, M., Dimich-Ward, H., Siersted, H. C., Ernst, P., Sweet, L., van Til, L., Bowie, D. M., Anthonisen, N. R., \& Tate, R. B. (2001). Prevalence of asthma symptoms among adults aged 20-44 years in Canada. Canadian Medical Association Journal, 164(7), 995-1001.

Manfreda, J., Sears, M. R., Becklake, M. R., Chan-Yeung, M., Dimich-Ward, H., Siersted, H. C., Ernst, P., Sweet, L., Van Til, L., Bowie, D. M., \& Anthonisen, N. R. (2004). Geographic and gender variability in the prevalence of bronchial responsiveness in Canada. Chest, 125(5), 1657-1664.

Mantzoukas, S. (2007). Qualitative research in 6 easy steps: The epistemology, methods and presentation. Nursing, 46(1), 236-246.

McLafferty, S. L. (2003). GIS and health care. Annual Review of Public Health, 24(1), 25-42.

Mikelova, L. K., Halperin, S. A., Scheifele, D., Smith, B., Ford-Jones, E., Vaudry, W., Jadavji, T., Law, B., \& Moore, D. (2003). Predictors of death in infants hospitalized with pertussis: a case-control study of 16 pertussis deaths in Canada. Journal of Pediatrics, 143(5), 576-581 Diekema et al., 2001.

O'Neill, L. (2003). Estimating out-of-hospital mortality due to myocardial infarction. Health Care Management Science, 6(3), 147-154 Viik-Kajander et al., 2003.

Oyana, T. J., \& Rivers, P. A. (2005). Geographic variations of childhood asthma hospitalization and outpatient visits and proximity to ambient pollution sources at a U.S.-Canada border crossing. International Journal of Health Geographics, 4(Jun 8), 14.

Oyana, T. J., Rogerson, P., \& Lwebuga-Mukasa, J. S. (2004). Geographic clustering of adult asthma hospitalization and residential exposure to pollution at a United States-Canada border crossing. American Journal of Public Health, 94(7), 1250-1257 Manfreda et al., 2004.

Park, J.-I., \& Kwon, H.-S. (2019). Examining the association between socioeconomic status and exposure to carcinogenic emissions in Gyeonggi of South Korea: A multi-level analysis. Sustainability, 11(6), 1777.

Park, S., Cho, J., \& Chen, Y.-C. (2019). Subsidized housing and geographic accessibility to neighborhood resources for low-income older people: From later year social exclusion perspective. Geoforum, 106, 297-304.

Rogers, D. J., \& Randolph, S. E. (2003). Studying the global distribution of infectious diseases using GIS and RS. Nature Reviews Microbiology, 1(3), 231-237.

Ruiz, M. O., \& Remmert, D. (2004). A local department of public health and the geospatial data infrastructure. Journal of Medical Systems, 28(4), 385-395 Zubieta et al., 2003.

Sattenspiel, L., \& Herring, D. A. (2003). Simulating the effect of quarantine on the spread of the 1918-19 flu in central Canada. Bulletin of Mathematical Biology, 65(1), 1-26 Boulos K., Nabih M. 2004.

Sattenspiel, L., Mobarry, A., \& Herring, D. A. (2000). Modeling the influence of settlement structure on the spread of influenza among communities. American Journal of Human Biology: Official Journal of the Human Biology Council, 12(6), 736-748.

Sauchyn, D. J. (2001). Modeling the hydroclimatic disturbance of soil landscapes in the southern Canadian Plains: The problems of scale and place. Environmental Monitoring and Assessment, 67(1-2), 277-291.

Singh, S. K., \& Taylor, R. W. (2020). Assessing and mapping human health risks due to arsenic and socioeconomic correlates for proactive arsenic mitigation arsenic water resources contamination (pp. 231-256): Springer.

Uphoff, H., Stalleicken, I., Bartelds, A., Phiesel, B., \& Kistemann, B. T. (2004). Are influenza surveillance data useful for mapping presentations? Virus Research, 103(1-2), 35-46.

Veugelers, P. J., Page, K. A., Tindall, B., Schechter, M. T., Moss, A. R., Winkelstein, W. W., Cooper, D. A., Craib, K. J., Charlebois, E., Coutinho, R. A., et al. (1994). Determinants of HIV disease progression among homosexual men registered in the tricontinental seroconverter study. American Journal of Epidemiology, 140(8), 747-758 Uphoff et al., 2004.

Viik-Kajander, M., Moltchanova, E., Salomaa, V., Tuomilehto, J., Ketonen, M., Palomäki, P., Miettinen, H., Pyörälä, K., \& Karvonen, M. (2009). Geographical variation in the incidence of acute myocardial infarction in eastern Finland - A Bayesian perspective. Annals of Medicine, 35(1), 43-50.

Wellie, O., Duhme, H., Streit, U., von Mutius, E., Keil, U., \& Weiland, S. K. (2000). Application of geographical information systems in epidemiological studies exemplified by the ISAAC study in Munich [in German]. Gesundheitswesen, 62(8-9), 423-430. 
Wilson, B., Wilson, N., \& Martin, S. (2019). Using GIS to advance social economics research: Geocoding, aggregation, and spatial thinking. Paper presented at the Forum for Social Economics.

Yang, N., \& Kim, K. (2020). Qualitative study on the perception of community food-accessibility environment among urban older adults. Korean Journal of Community Nutrition, 25(2), 137-149.

Zang, P., Lu, Y., Ma, J., Xie, B., Wang, R., \& Liu, Y. (2019). Disentangling residential self-selection from impacts of built environment characteristics on travel behaviors for older adults. Social Science \& Medicine, 238, 112515.

Zubieta, J. C., Skinner, R., \& Dean, A. G. (2003). Initiating informatics and GIS support for a field investigation of bioterrorism: The New Jersey anthrax experience. International Journal of Health Geographics, 2(1), 8 .

Publisher's Note Springer Nature remains neutral with regard to jurisdictional claims in published maps and institutional affiliations. 